RESEARCH PAPER

\section{Elucidation of}

\section{flow-mediated tumour}

cell-induced platelet

aggregation using an

ultrasound standing

wave trap

\author{
D Bazou ${ }^{1}$, MJ Santos-Martinez ${ }^{1,2,3}$, C Medina $^{2}$ and MW Radomski ${ }^{1,2}$ \\ ${ }^{1}$ Centre for Research on Adaptive Nanostructures and Nanodevices, Trinity College Dublin, \\ Dublin, Ireland, ${ }^{2}$ School of Pharmacy and Pharmaceutical Sciences, Trinity College Dublin, \\ Dublin, Ireland, and ${ }^{3}$ School of Medicine, Trinity College Dublin, Dublin, Ireland
}

\section{Correspondence}

Marek W. Radomski, School of Pharmacy and Pharmaceutical Sciences, Trinity College Dublin, Dublin 2, Ireland. E-mail: marek.radomski@tcd.ie

\section{Keywords}

platelets; tumour; suspension; ultrasound; disruption; aggregation

Received

16 July 2010

Revised

10 November 2010

Accepted

17 November 2010

\title{
BACKGROUND AND PURPOSE
}

Tumour cells activate and aggregate platelets [tumour cell-induced platelet aggregation (TCIPA)] and this process plays an important role in the successful metastasis of cancer cells. To date, most studies on TCIPA have been conducted under no-flow conditions. In this study, we have investigated TCIPA in real time under flow conditions, using an ultrasound standing wave trap that allows formation and levitation of cancer cell clusters in suspension, thus mimicking the conditions generated by flowing blood.

\section{EXPERIMENTAL APPROACH}

Using 59M adenocarcinoma and HT1080 fibrosarcoma cells and human platelets, cancer cell cluster-platelet aggregates were imaged in real time using epi-fluorescence microscopy (F-actin) and investigated in detail using confocal microscopy (matrix metalloproteinase-2-GPIIb/IIla co-localization) and scanning electron and helium-ion microscopy ( $<1 \mathrm{~nm}$ resolution). The release of gelatinases from aggregates was studied using zymography.

\section{KEY RESULTS}

We found that platelet activation and aggregation takes place on the surface of cancer cells (TCIPA), leading to time-dependent disruption of cancer cell clusters. Pharmacological modulation of TCIPA revealed that EDTA, prostacyclin, o-phenanthroline and apyrase significantly down-regulated TCIPA and, in turn, delayed cell cluster disruption, However, EGTA and aspirin were ineffective. Pharmacological inhibition of TCIPA correlated with the down-regulation of platelet activation as shown by flow-cytometry assay of platelet P-selectin.

\section{CONCLUSION AND IMPLICATIONS}

Our results show for the first time, that during TCIPA, platelet activation disrupts cancer cell clusters and this can contribute to metastasis. Thus, selective targeting of platelet aggregate-cancer cell clusters may be an important strategy to control metastasis.

\footnotetext{
Abbreviations

DMEM, Dulbecco's modified Eagle's medium; DVT, deep vein thrombosis; F-actin, filamentous-actin; FCS, foetal calf serum; He-Ion SM, helium-ion scanning microscopy; MEM, modified Eagle's medium; MMP-2, matrix metalloproteinase-2; PCF, platelet contractile force; PE, pulmonary embolism; PGI $_{2}$, prostacyclin; SDS-PAGE, sodium dodecyl sulfate-polyacrylamide gel electrophoresis; SEM, scanning electron microscopy; TCIPA, tumour cell-induced platelet aggregation; $\mathrm{TXA}_{2}$, thromboxane $\mathrm{A}_{2}$; USWT, ultrasound standing wave trap
} 


\section{Introduction}

The ability of cancer cells to metastasize is one of the major obstacles to the development of successful cancer therapies. The metastatic cascade is a highly coordinated process in which cancer cells undergo extensive interactions with a variety of host cells before they establish a secondary metastatic colony (Honn et al., 1992). The involvement of platelets in haematogenous metastasis has long been recognized. A relationship between venous thromboembolism and cancer was first observed by Trousseau (1865), while more recent studies have shown that the risk of diagnosis of cancer was clearly elevated after primary deep vein thrombosis (DVT) or pulmonary embolism (PE) (Sørensen et al., 1998).

Tumour cell-induced platelet aggregation (TCIPA) presents a number of advantages to the successful metastasis of cancer cells (Jurasz et al., 2001a). It has been reported that when cancer cells are covered with platelets, they acquire the ability to elude the body's immune system (Philippe et al., 1993; Palumbo et al., 2005). Secondly, several growth factors supporting tumour growth and angiogenesis are released by platelets (Jurasz et al., 2001b; Nierodzik and Karpatkin, 2006; Borsig, 2008). Thirdly, platelets may also protect cancer cells from high shear forces seen in flowing blood that could potentially damage tumour cells (Jurasz et al., 2004). Recent findings have also shown that platelets are essential for regulating haemostasis in tumour vasculature (Ho-Tin-Noé et al., 2008; 2009). Finally, the large tumour cell-platelet aggregate can embolize the microvasculature at a new extravasation site (Jurasz et al., 2001a). To this end, the development of thromboembolic diseases, such as DVT and PE in cancer patients, is not uncommon (Winter, 2006). Wahrenbrock et al. (2003) reported that circulating carcinoma mucins interact with platelet P-selectin and leukocyte L-selectin; these interactions generate platelet-rich microthrombi without thrombin production and can lead to the development of metastases (Khorana and Fine, 2004).

High rates of DVT occur with advanced pancreatic, breast, ovarian, germ cell, lung, prostate and CNS cancers (Linenberger and Wittkovsky, 2005). Lim et al. (2010) reported that $18.6 \%$ of women with epithelial ovarian carcinoma had DVT, while a third of this percentage of women had also PE. The reason for this is that in patients with ovarian cancer, the combination of an increase in red blood cell aggregation and plasma viscosity impairs blood-flow properties and may induce hypoxia in the microcirculation that in turn favours thrombosis, settlement of tumour cells and thus metastasis (Von Tempelhoff et al., 1998).

Such advantages conferred to tumour cells by platelets are only relevant during the early stages of metastasis, that is, from the time the tumour cell enters the bloodstream to the moment of successful extravasation of the tumour cell (Erpenbeck and Schön, 2010).

Several mechanisms are involved in TCIPA; for example, tumour cells can activate platelets by thrombin generation, releasing $\mathrm{ADP}$, thromboxane $\mathrm{A}_{2}\left(\mathrm{TXA}_{2}\right)$ and matrix metalloproteinase (MMP)-2 (Alonso-Escolano et al., 2004; VargaSzabo et al., 2008), whereas the adhesion receptors GPIb-IX-V, GPIIb/IIIa and P-selectin are also implicated (Jurk and Kehrel, 2005; Angiolillo et al., 2010). Indeed, not only cancer cells have the ability to stimulate platelet receptor expression, but also platelets themselves up-regulate GPIb and GPIIb/IIIa on the surface of cancer cells (Santos-Martinez et al., 2008).

To date, different in vitro models of TCIPA have been used; however, most of the studies performed so far have been under no-flow conditions using light aggregometry. Because platelets are stirred to maintain a suspension and induce tumour cellplatelet interactions, these take place under the influence of fluid mechanical shear stress. However, the shear stress varies throughout the stirred platelet suspension and does not mimic flow and shear rates encountered in the bloodstream. In this study, we have investigated in real time and in a flowdependent manner, the process of TCIPA, using a 2D ultrasound standing wave trap (USWT) (Figure 1A,B) that allows levitation of cell clusters in suspension (Bazou et al., 2005a,b; 2006). The resulting 2-D cancer cell cluster provides good resolution capability for optical examination of cell-cell interactions in real time in the trap. Such a significant development in cell manipulation allowed us to revisit TCIPA and refine our understanding of tumour cell-platelet interactions. In our study, we aimed at investigating whether human ovarian carcinoma and fibrosarcoma cells were capable of TCIPA under flow conditions and whether several pharmacological inhibitors of platelet aggregation would modulate TCIPA in vitro. We show that platelet activation and aggregation takes place on the surface of cancer cells during flow-induced TCIPA leading to time-dependent cancer cell cluster disruption.

\section{Methods}

\section{Cell culture}

The human cell lines 59M (ovarian adenocarcinoma) and HT1080 (fibrosarcoma) were obtained from the European Collection of Cell Cultures (Salisbury, UK). Cell lines were maintained at $37^{\circ} \mathrm{C}$ in a humidified atmosphere with $5 \% \mathrm{CO}_{2} .59 \mathrm{M}$ cells were cultured in Dulbecco's modified Eagle's medium supplemented with $0.0007 \mathrm{~g} \cdot \mathrm{L}^{-1}$ insulin, $100 \mu \mathrm{g} \cdot \mathrm{mL}^{-1}$ penicillin-streptomycin solution, $0.05 \mathrm{~g} \cdot \mathrm{L}^{-1}$ sodium pyruvate and $10 \%$ fetal calf serum (FCS). The medium was changed every third day. HT1080 cells were cultured in MEM with gentamycin $\left(0.05 \mathrm{mg} \cdot \mathrm{mL}^{-1}\right)$, penicillin $\left(0.06 \mathrm{mg} \cdot \mathrm{mL}^{-1}\right)$, streptomycin $\left(0.01 \mathrm{mg} \cdot \mathrm{mL}^{-1}\right)$ and $10 \%$ FCS. At confluence, cells were detached with Accutase (Sigma, Wicklow, Ireland), resuspended in serum-free (D)MEM, counted and finally diluted to $5 \times 10^{5} \mathrm{~mL}^{-1}$. Samples were introduced into the trap with a $2 \mathrm{~mL}$ sterile syringe (Plastipak, Becton Dickinson, Oxford, UK).

\section{Ultrasound trap}

The ultrasound trap (Figure 1B) had three essential features: a transducer (Ferroperm, Kvistgard, Denmark) in a housing of radial symmetry, an aqueous phase and a reflector that provided optical access from above as previously described (Bazou et al., 2005a,b). The trap was driven with a function generator (Hewlett Packard 33120A, Bristol, UK).

\section{Optical system}

A fast, high-resolution XM10 camera (Soft Imaging System, SIS, GmbH, Münster, Germany) mounted on an Olympus BX51M (Tokyo, Japan) reflection epi-fluorescence microscope 
A

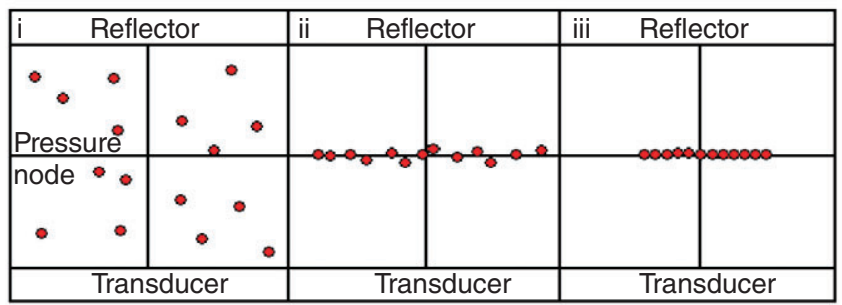

B

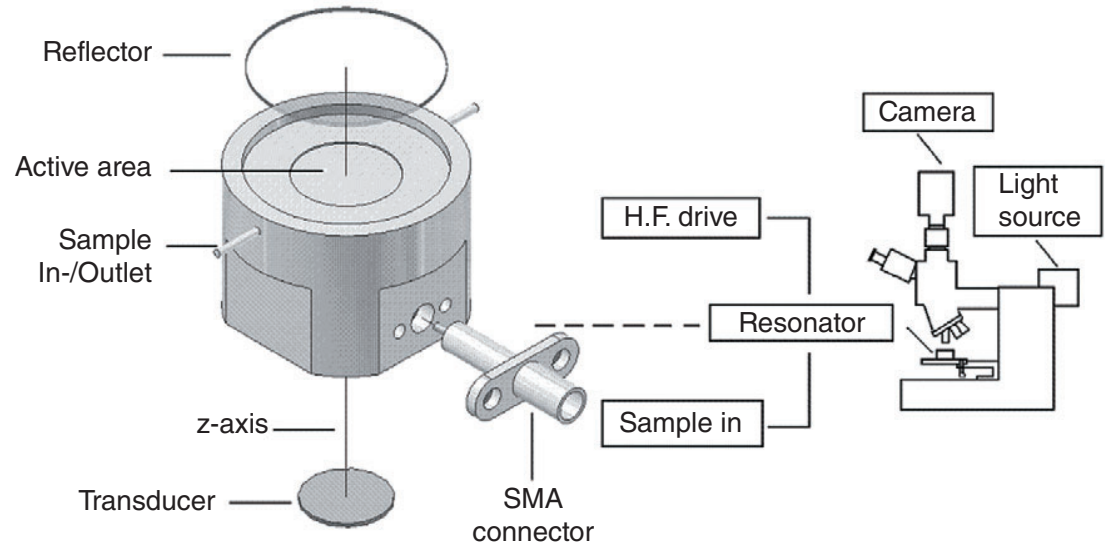

\section{Figure 1}

(A) Schematic diagram of the temporal progression [from time zero (i) to less than $1 \mathrm{~s}$ (ii) to tens of seconds (iii)] of cell aggregation in the trap. (B) Schematic diagram of the trap, epi-microscope, sample loading and ultrasound generation. Reproduced with permission from Bazou et al. (2005b).

allowed observation in the direction of sound propagation. Images were captured by a standard PC equipped with the Cell-D image acquisition software and processed using the Cell-P software (Soft Imaging System).

\section{Platelets}

Blood was collected from healthy volunteers with informed consent, who had not taken any drugs known to affect platelet function for at least 14 days prior to the study. Washed platelet suspensions were prepared from blood in Tyrode's solution as previously described $\left(2.5 \times 10^{8}\right.$ platelets $\left.\cdot \mathrm{mL}^{-1}\right)$ (Radomski and Moncada, 1983).

\section{F-actin immmunofluorescence}

$59 \mathrm{M}$ cells were used in these experiments. A cluster of approximately $1 \mathrm{~mm}$ diameter was formed within $30 \mathrm{~s}$ of ultrasound exposure. Clusters were exposed to ultrasound for 1 and $10 \mathrm{~min}$. They were removed from the trap using a $2 \mathrm{~mL}$ syringe, placed on a HistoBond microscope slide (RA Lamb, Eastbourne, UK) and fixed with 90\% ethanol. After rinsing with saline, F-actin was labelled by adding $2 \mathrm{U} \cdot \mathrm{mL}^{-1}$ of Phalloidin-Alexa 488 conjugate (Invitrogen, Renfrewshire, UK). The slides were incubated at room temperature in the dark, rinsed and mounted in Vectashield (Vector, Peterborough, UK). The integral intensity of the phalloidin staining at the cell interface was quantified by placing a rectangle provided by the Cell-P software, to contain the interface of each of the 20 randomly selected pairs of cells.
Tumour cell aggregate-platelet interactions: experimental procedure

$59 \mathrm{M}$ and HT1080 cells were introduced into the trap, the acoustic field $(2.13 \mathrm{MHz}, 0.85 \mathrm{MPa})$ was initiated and clusters were allowed to form. Clusters remained levitated in suspension for $10 \mathrm{~min}$. Washed platelets were introduced into the trap at a flow rate of $3 \mu \mathrm{L} \cdot \mathrm{min}^{-1}$. Perfusion of washed platelets around the cluster proceeded following initial adhesion of platelets to the periphery of the cluster. The cell clusterplatelet aggregate remained under microscopic observation for further $10 \mathrm{~min}$ under continuous flow conditions. In another set of experiments, flow was terminated following $30 \mathrm{~s}$ of platelet perfusion around the cell aggregate (static/ batch mode). Microscopic observation proceeded as described previously.

\section{TCIPA pharmacology}

To study the involvement of $\mathrm{TXA}_{2^{-}}$, ADP- and MMP-2dependent pathways in TCIPA, washed platelets were preincubated for $3 \mathrm{~min}$ at room temperature with the inhibitors of these pathways such as aspirin $(150 \mu \mathrm{M})$, apyrase $\left(500 \mu \mathrm{g} \cdot \mathrm{mL}^{-1}\right)$ and $o$-phenanthroline $(500 \mu \mathrm{M})$ (AlonsoEscolano et al., 2004) prior to their introduction into the trap. Prostacyclin $\left(\mathrm{PGI}_{2} ; 10 \mathrm{ng} \cdot \mathrm{mL}^{-1}\right)$, EDTA $(5 \mathrm{mM})$ and EGTA (5 mM) were also used. A low, sub-physiological concentration of platelets $\left(80000 \mu \mathrm{L}^{-1}\right)$ as well as red blood cells $\left(250000 \mu \mathrm{L}^{-1}\right)$ served as controls. 


\section{MMP-2/PAC-1 immmunofluorescence}

Immunofluorescence staining was performed on the $59 \mathrm{M}$ cell cluster-platelet aggregate. The aggregate samples were recovered from the trap immediately after platelet activation was initiated. They were then placed on a HistoBond microscope slide (RA Lamb) and fixed with 90\% ethanol. To avoid further platelet activation, the microscope slides were siliconized as described by Gfeller et al. (2005). Samples were then incubated with $50 \mu \mathrm{L}$ of PAC-1-FITC conjugate $(20 \mu \mathrm{L}$ per $5 \mu \mathrm{L}$ suspension; Becton Dickinson, Rutherford, NJ, USA) for $30 \mathrm{~min}$ at room temperature in the dark; PAC-1 recognizes an epitope on the glycoprotein GPIIb/IIIa complex of activated platelets in live cells. Samples were then fixed with 90\% ethanol followed by the addition of mouse anti-MMP-2 $\left(2 \mu \mathrm{g} \cdot \mathrm{mL}^{-1}\right.$, Millipore, Billerica, MA, USA) monoclonal antibody overnight at $4^{\circ} \mathrm{C}$. After washing in phosphate-buffered saline, samples were incubated with Alexa 594 conjugated anti-mouse IgG $\left(5 \mu \mathrm{g} \cdot \mathrm{mL}^{-1}\right.$; Invitrogen) for $1 \mathrm{~h}$ in the dark. After further washing $(\times 3)$, the slides were mounted in DAPIVectashield (Vector).

\section{Confocal microscopy}

Specimens were examined using an Olympus FV1000 PointScanning Confocal Microscope (Olympus) that was controlled via standard Pentium PC running FluoView image acquisition software (Olympus). Z-stacks of optical sections were taken through the entire volume of the aggregates at $0.9 \mu \mathrm{m}$ intervals. Z-stacks were processed and analysed using FluoView.

\section{Electron and helium-ion scanning microscopy}

Electron and helium-ion scanning microscopy (SEM and He-Ion SM) were performed on the 59M cell cluster-platelet aggregate samples. Samples were placed on nylon membrane filters (Nylaflo, Pall Life Sciences, Port Washington, NY, USA) and fixed with 3\% glutaraldehyde for 20 min. Samples were dehydrated in a Zeiss Supra Variable Pressure Field Emission Scanning Electron Microscope (Hertfordshire, UK), while images were also captured with a Zeiss Orion Plus Helium-Ion Microscope.

\section{Flow cytometry}

The abundance of P-selectin on the surface of platelets during TCIPA was measured by flow cytometry. Platelets were activated with tumour cells in the presence or absence of $\mathrm{PGI}_{2}$, aspirin, $o$-phenanthroline or apyrase, which were added 3 min prior to introduction of platelets around the tumour cells. One minute after initiation of aggregate disruption, the reaction was terminated. Resting platelets were used as the control. Platelet samples were then incubated in the dark for $5 \mathrm{~min}$ at room temperature in the presence of saturating concentrations $\left(10 \mu \mathrm{g} \cdot \mathrm{mL}^{-1}\right)$ of antibody to P-selectin (CD62P-APC, BD Biosciences, Oxford, UK). Following incubation, samples were diluted in fluorescence-activated cell sorting (FACS) flow fluid and analysed within 5 min using a BD FACSArray (BD Biosciences). Flow cytometry was performed on single-stained platelet samples as described before (Radomski et al., 2005). Antibody binding was measured by analysing individual platelets for fluorescence. The mean fluorescence intensity was determined after correction for cell autofluorescence. For each sample, the fluorescence was analysed using a logarithmic scale. Fluorescence histograms were obtained for 10000 individual events. Data were analysed using BD FACSArray system Software v1.0.3 (BD Biosciences).

\section{Gelatin zymography}

Gelatin zymography was performed to detect the gelatinase activity. Zymographic analysis was performed on 59Mplatelet supernatants, as described previously (Medina et al., 2006). Samples were subjected to $8 \%$ sodium dodecyl sulfatepolyacrylamide gel electrophoresis with co-polymerized gelatin $\left(2 \mathrm{mg} \cdot \mathrm{mL}^{-1}\right)$ incorporated as a substrate for gelatinolytic proteases. Following electrophoresis, gels were washed three times for $20 \mathrm{~min}$ in $2.5 \%$ Triton X-100 and twice for $20 \mathrm{~min}$ in developing buffer $(50 \mathrm{mM}$ Tris- $\mathrm{HCl} \mathrm{pH}$ 7.6, $150 \mathrm{mM} \mathrm{NaCl}, 5 \mathrm{mM} \mathrm{CaCl}_{2}$ and $0.05 \% \mathrm{NaN}_{3}$ ) and then incubated $37^{\circ} \mathrm{C}$ in developing buffer for 7 days. Gels were stained in $40 \%$ methanol, $10 \%$ acetic acid and $0.1 \%(\mathrm{w} / \mathrm{v})$ Coomassie Blue R-250 for $1 \mathrm{~h}$ and then destained in a $4 \%$ methanol and $8 \%$ acetic acid solution. The gelatinolytic activities were detected as transparent bands against the background of Coomassie Blue-stained gelatin. The conditioned medium of HT1080 human fibrosarcoma cells (that contains high amounts of proMMP-2 and MMP-2) was used as control. The intensities of the separate bands were analysed and quantified using the ChemiDoc XRS System (Biorad, Alpha Technologies, Dublin, Ireland).

\section{Statistics}

The data are shown as mean \pm SEM. Analysis of means was performed with a two-tailed, two sample, Student's $t$-test or one-way ANOVA (GraphPad Prism software, San Diego, CA, USA). Where data were not normally distributed or of unequal variance, the Mann-Whitney test was performed. Differences were considered significant at $P$ values less than 0.05 .

\section{Materials}

All reagents were purchased from Sigma-Aldrich Limited (Wicklow, Ireland) unless otherwise indicated.

\section{Results}

\section{Cluster cell growth and morphology}

59M and HT1080 cells moved into the optically focused nodal plane of the ultrasound trap within $1 \mathrm{~s}$ of initiation of sonication. Single cells and small clusters (consisting of 5-10 cells) moved towards the central clustering area within $10 \mathrm{~s}$; a small cluster had formed $20 \mathrm{~s}$ later at the central region of the nodal plane (Video S1). On contact with the main cluster, the cells rearranged themselves to accommodate the cluster's peripheral cells in the contact region so that the growing cluster developed as a closely packed form. A cluster was fully formed within 2 min of initiation of ultrasound, as characterized by the absence of free single cells in the field of view. Cluster diameters were $1.0-1.5 \mathrm{~mm}$, while the number of cells in the cluster was in the range of 10000 cells. Aggregates remained levitated in the trap for $10 \mathrm{~min}$ prior to platelet perfusion. 


\section{F-actin localization}

Non-sonicated samples of $59 \mathrm{M}$ cells presented a diffuse F-actin network throughout the cells (Figure 2A). Following 1 min of cell-cell contact in the trap, actin label accumulated at the interfaces of cells (Figure 2B) at low intensities, while 9 min later high-intensity labelling was shown at the cell-cell contact region (Figure 2C). The average integral intensity of F-actin, for 20 randomly selected paired cells, showed a threefold increase from 1 to $10 \mathrm{~min}$ of ultrasound exposure (Figure 2D).

\section{Tumour cell cluster-platelet aggregates and their disruption}

Following levitation of a 59M or HT1080 cell aggregate in the trap for $10 \mathrm{~min}$ (Figure 3A), platelet perfusion was initiated at $3 \mu \mathrm{L} \cdot \mathrm{min}^{-1}$. Platelets approached the aggregate within $1 \mathrm{~min}$ and established contact with its periphery. Complete platelet 'encapsulation' of the cancer cell cluster was seen within 2 min (Figure 3B; platelets are shown with black arrows). Platelet activation (visually identified as a progressive transition to a gel-like sheet around the tumour cell cluster) occurred within 3 min (average from five donors) from platelet-cell cluster contact and resulted in the cancer cluster disruption (Figure 3C,D). Figure 3D illustrates the disruption of the aggregate (black arrows), while the gel-like sheet of activated platelets surrounding the aggregate is shown with the white arrows. Flow conditions were maintained throughout the duration of the experiments. These results were also replicated under no-flow conditions. The Video S1 illustrates TCIPA under no-flow conditions from cluster growth to its disruption.

\section{Inhibition of TCIPA}

We used inhibitors of MMP-2, TXA 2 and ADP-dependent pathways of platelet aggregation (Sawicki et al., 1997) to
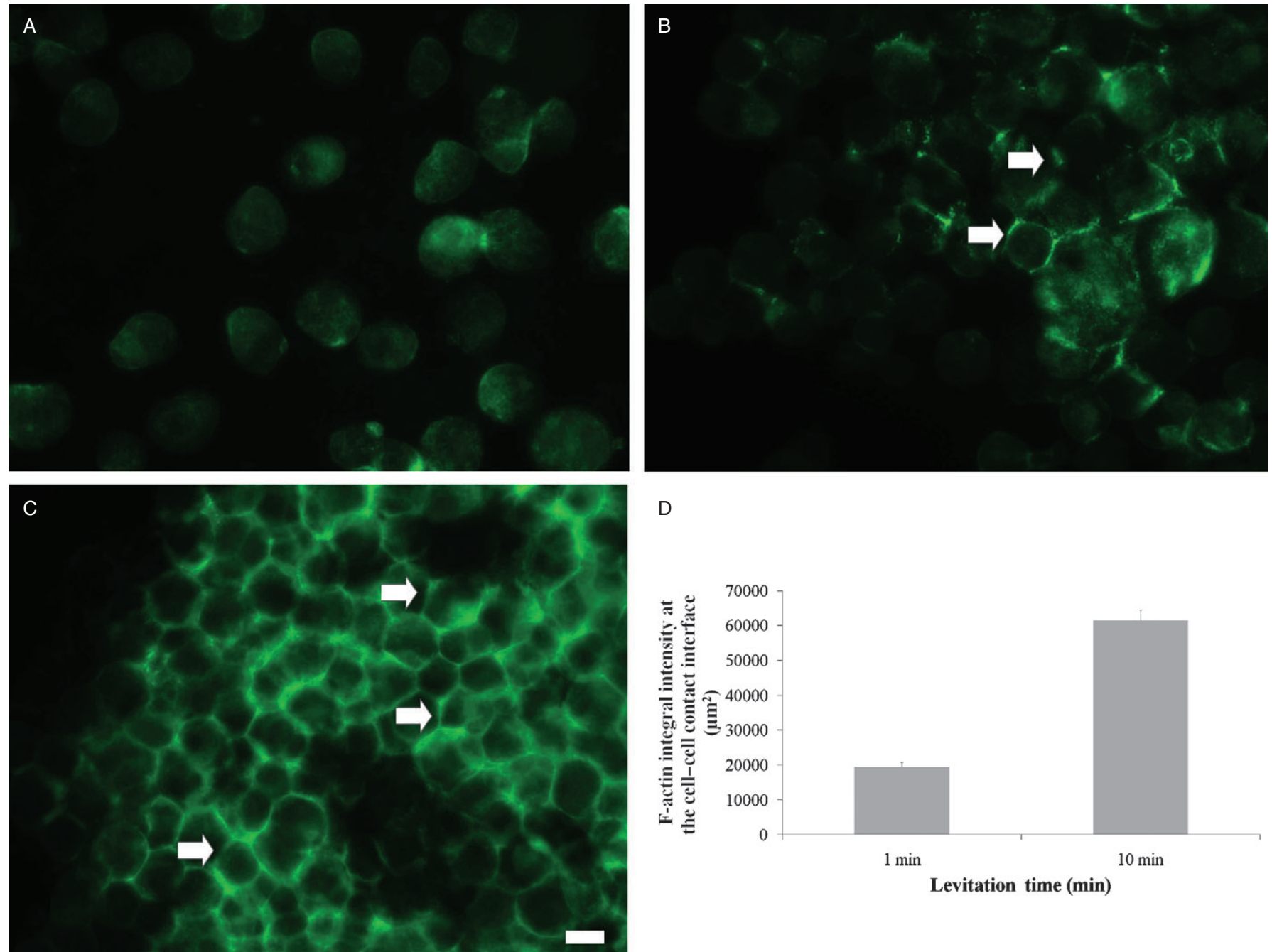

$\mathrm{D}$

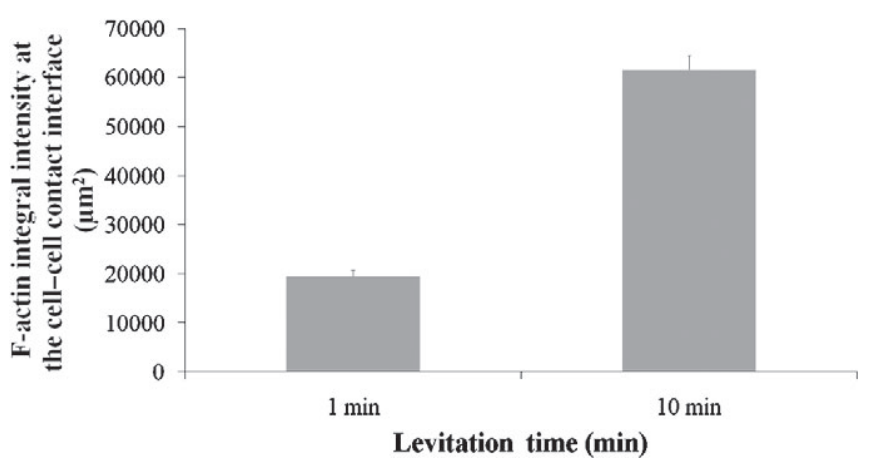

\section{Figure 2}

Representative micrographs of the distribution of F-actin in 59M cells. (A) Non-sonicated samples of single 59M cells presented a diffuse F-actin network. (B) A short F-actin interface is displayed between cells being in contact for 1 min in the trap (arrows). (C) Nine minutes later, strong labelling was shown at the cell-cell contact region (arrows). Scale bar is $15 \mu \mathrm{m}$. (D) Summary data for the integral intensity of F-actin, measured at 1 and 10 min of cell-cell contact for 20 randomly selected paired cells. 

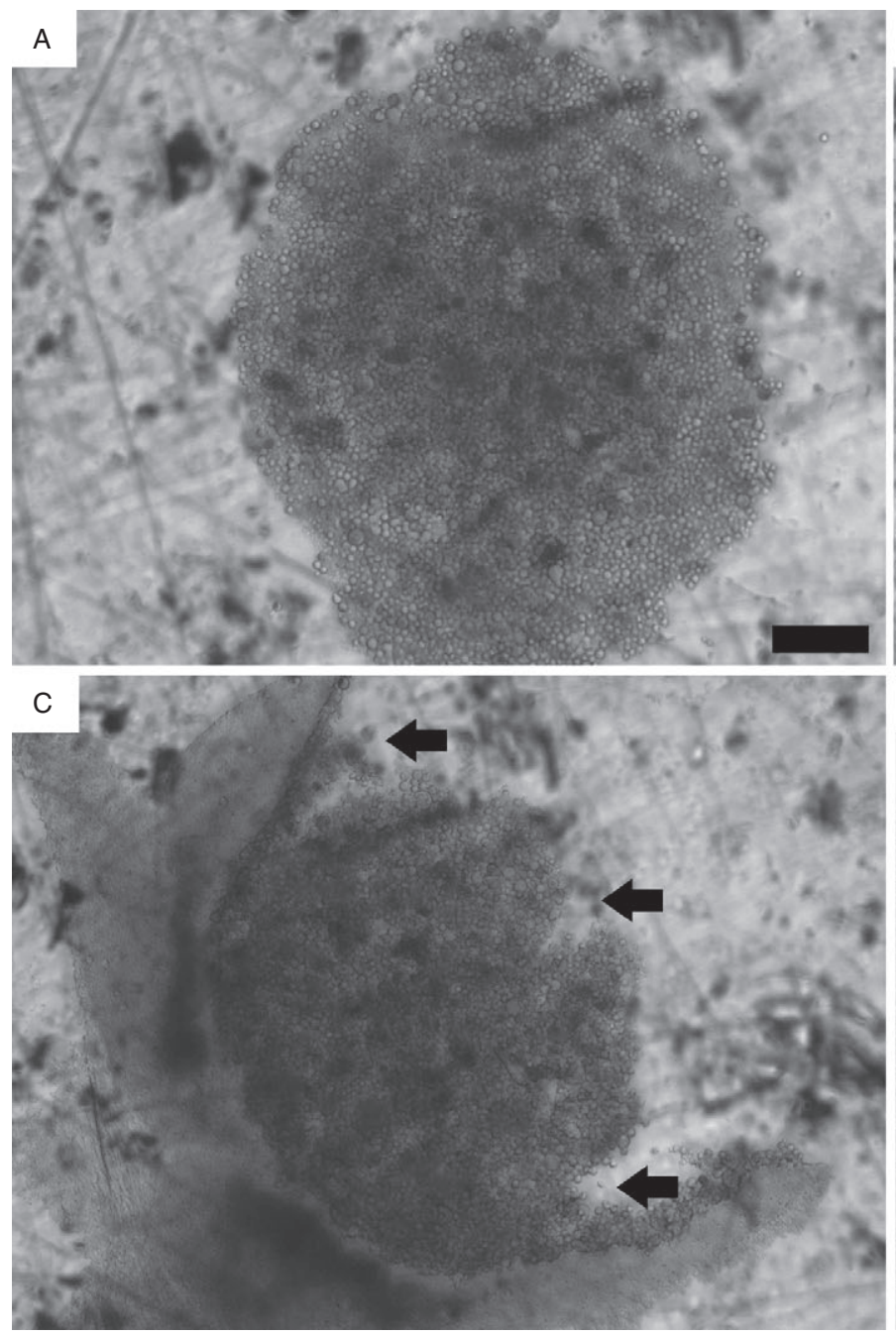
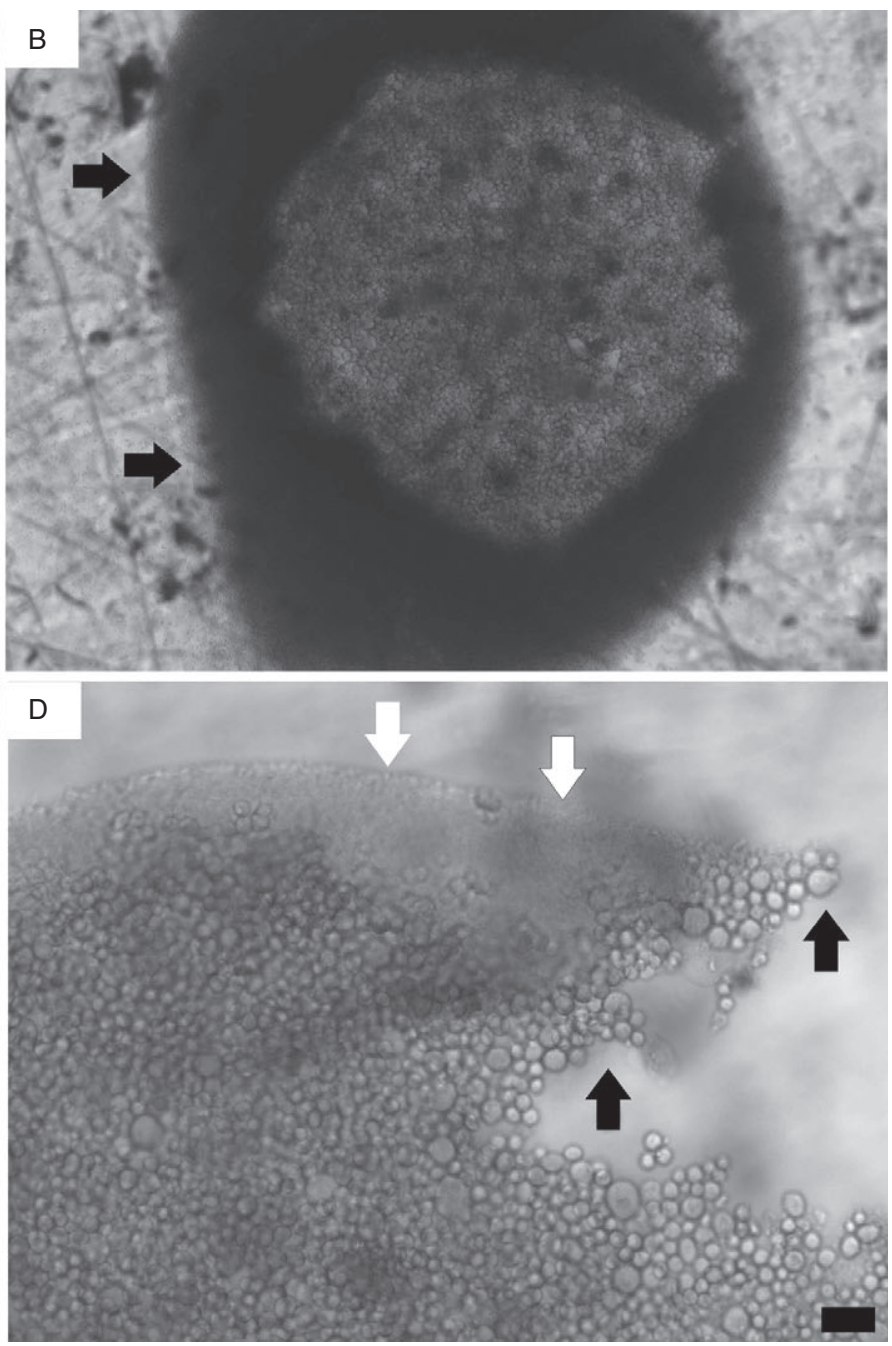

\section{Figure 3}

The progress of tumour cell-induced platelet aggregation as shown in the ultrasound standing wave trap. (A) A 59M ovarian tumour cell aggregate is levitated in the trap for $10 \mathrm{~min}$. (B) 2-D 'encapsulation' of tumour cell cluster by platelets shown with black arrows. (C) Platelet activation followed by aggregate disruption (black arrows). (D) Disruption of the cluster (black arrows) at $\times 10$ magnification, while the gel-like sheet of activated platelets surrounding the aggregate is shown with the white arrows. Scale bar in (A-C) is $200 \mu \mathrm{m}$; scale bar in (D) is $60 \mu \mathrm{m}$.

characterize 59M/HT1080-induced platelet aggregation. The most potent inhibitor of aggregation, $\mathrm{PGI}_{2}$ and metallic ion chelating agents such as EDTA and EGTA, were also employed. Figure 4 shows the results obtained from experiments conducted under flow conditions; those obtained under static conditions are shown in Figure S1 for both cell lines, while the effect of EGTA is shown in Figure S2 for the 59M cell line.

In the presence of $o$-phenanthroline and apyrase, $59 \mathrm{M}$ and HT1080-induced platelet aggregation was significantly reduced $(P<0.01$ for the $59 \mathrm{M}$ cells and $P<0.05$ for the HT1080 cells, $n=3$ ) (Figure 4A,B). Pre-incubation of platelets with aspirin, on the other hand, exerted no significant effect ( $P>0.05, n=3$ for both cell lines) (Figure 4A,B), while $\mathrm{PGI}_{2}$ and EDTA significantly arrested TCIPA for both cell lines $(P<$ $0.01, n=3$ ) (Figure 4A,B). In contrast, EGTA exerted no significant effect on 59M-induced platelet aggregation $(P>0.05$, $n=3$ ) (Figure S2).
The interaction of $59 \mathrm{M}$ cells with platelets at a subphysiological concentration (80 000 platelets $\left.\mu \mathrm{L}^{-1}\right)$ resulted in TCIPA initiation $(P<0.05)$; however, tumour aggregate disruption was only marginal and confined to a very small area of the cluster. Red blood cells $\left(250000 \mu \mathrm{L}^{-1}\right)$ exerted no significant effect on TCIPA and cluster disruption $(P<0.01, n=3)$, clearly showing that cancer cell disruption is an effect attributable only to platelet activation and aggregation.

\section{MMP-2/PAC-1 immmunofluorescence}

Immunofluorescence was used to assess the expression of MMP-2 and activated GPIIb/IIIa (PAC-1) during 59Minduced platelet aggregation. A 59M tumour cell-platelet cluster was removed from the trap following platelet activation, that is, within 2-4 min (platelet activation was 
A
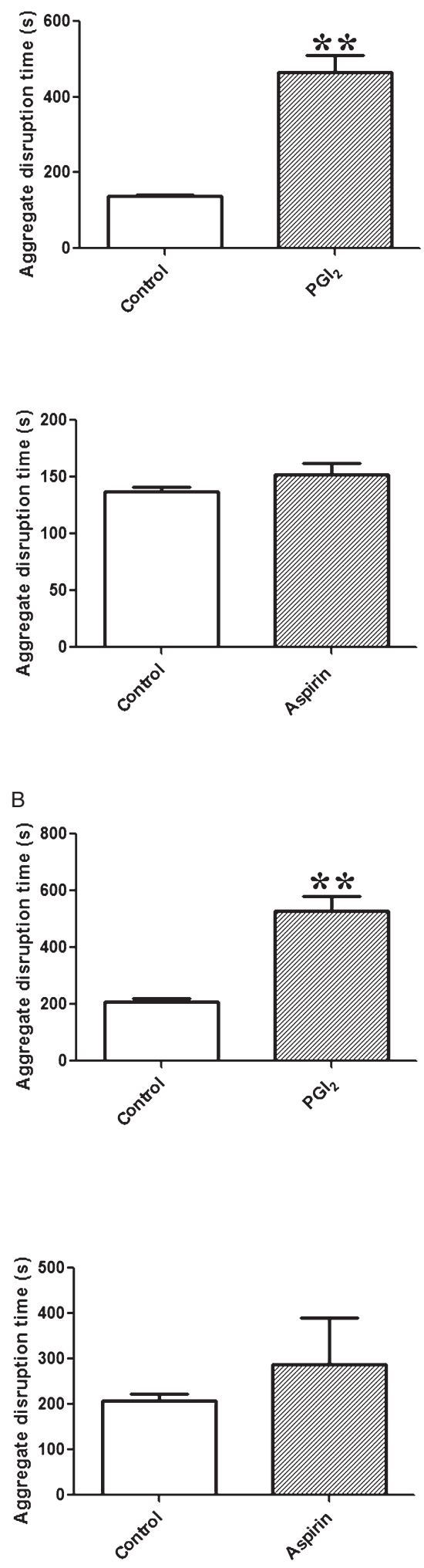
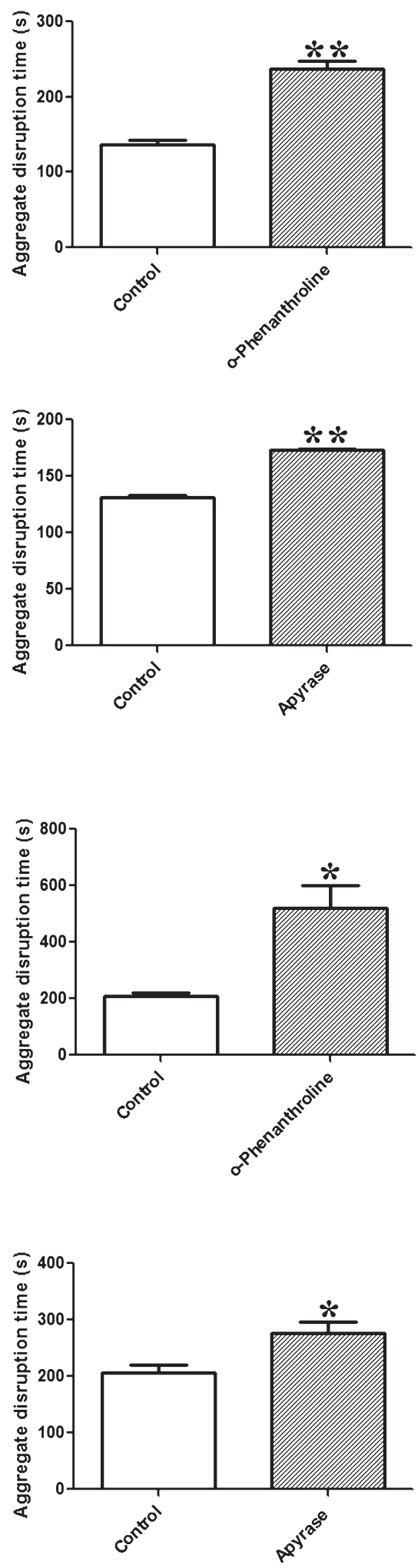
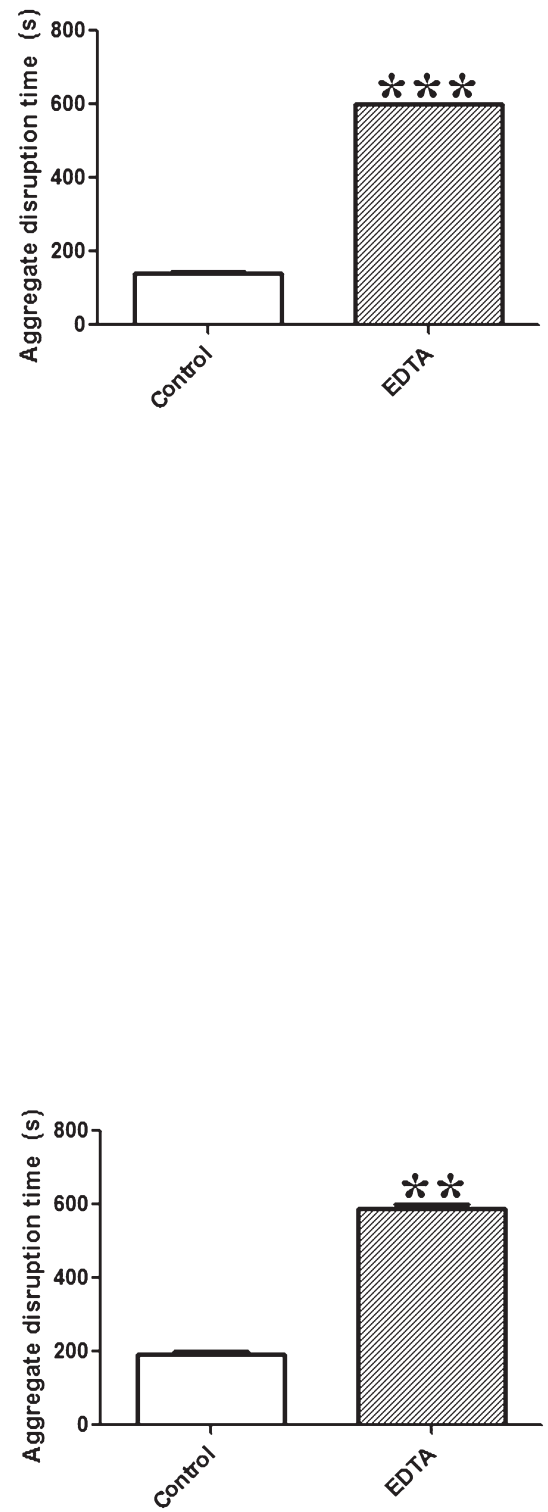

\section{Figure 4}

Pharmacological inhibition of tumour cell-induced platelet aggregation (TCIPA) for (A) 59M and (B) HT1080 cell lines under flow conditions. In the presence of o-phenanthroline or apyrase, TCIPA was inhibited (disruption time increased) for both 59M $(P<0.01)$ and HT1080 $(P<0.05)$. Pre-incubation of platelets with aspirin exerted no significant effect; however prostacyclin $\left(\mathrm{PGI}_{2}\right)$ and EDTA significantly arrested TCIPA for both cell lines $(P<0.01)$. 


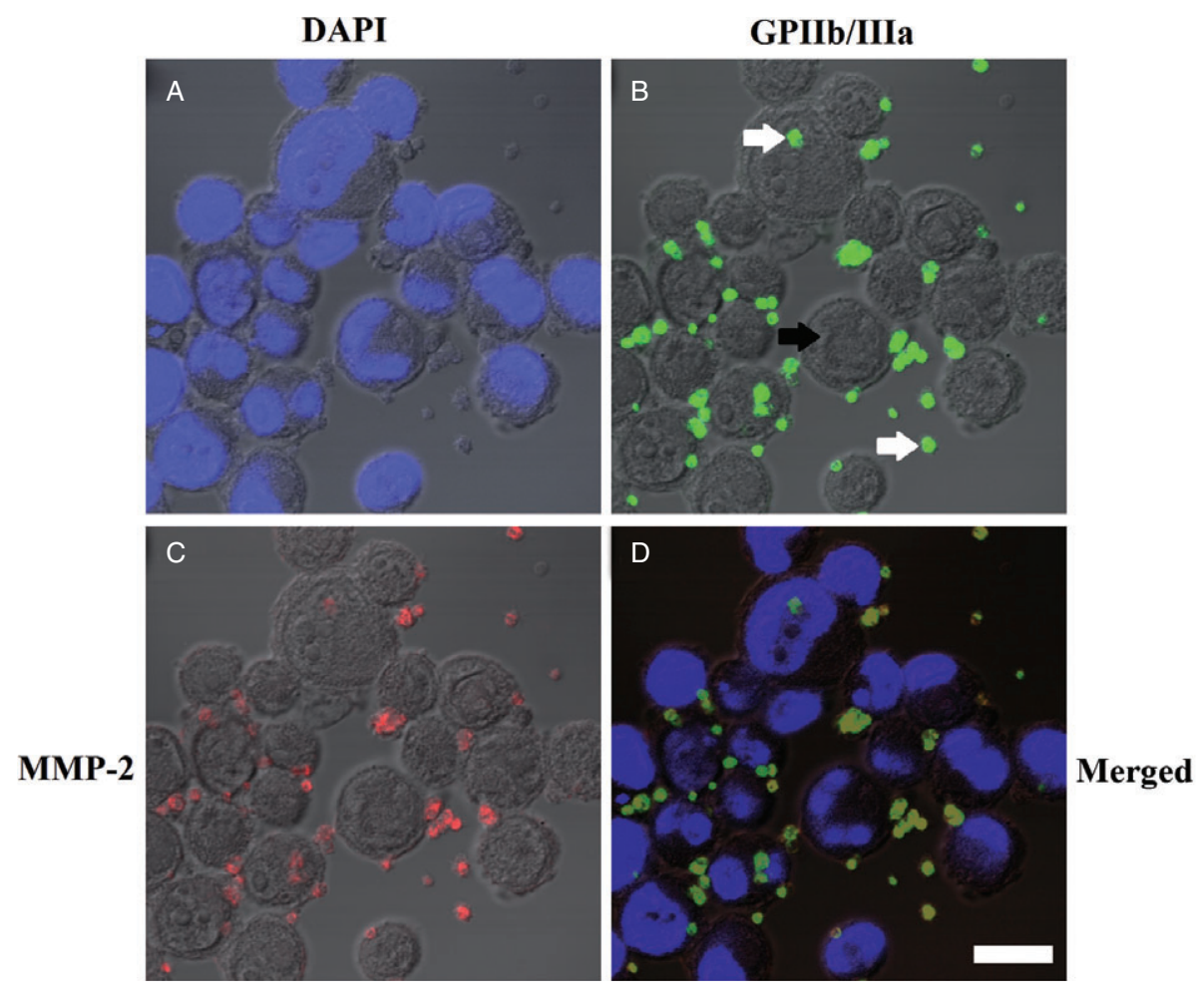

\section{Figure 5}

Representative confocal microscopy of tumour cell-induced platelet aggregation in 59M cells. (A) Bright-field micrograph of part of a 59M tumour cell aggregate superimposed with DAPI (nuclear staining). (B) GPIIb/IIla, as well as secreted MMP-2 (C), were localized at the surface of activated platelets (platelets are indicated with the white arrows, while tumour cells are indicated with the black arrow). (D) The superimposed image shows almost complete co-localization of GPIIb/IIla and MMP-2 at the platelet surface. Scale bar is $30 \mu \mathrm{m}$.

visually established). Upon removal from the trap, the cluster dissociated into small 2-D clumps (typically consisting of 10-50 cells) following deposition on the glass slide. Images were captured from all the fragments of the aggregate, providing examples of the typical recurring patterns characteristic of a sample, as in Figure 5A-D. Our results show that GPIIb/IIIa (Figure 5B) as well as secreted MMP-2 (Figure 5C) were localized at the surface of activated platelets (in Figure 5B platelets are indicated with the white arrows, while tumour cells are indicated with the black arrow). The superimposed image (Figure 5D) shows almost complete co-localization of GPIIb/IIIa and MMP-2 at the platelet surface.

\section{Gelatin zymography}

We then studied the gelatinase activity during 59M-induced platelet aggregation. As shown in Figure S3A-C, 59M cellinduced platelet aggregation resulted in increased levels of proMMP-2/MMP-2 and proMMP-9/MMP-9 activities being released $(P<0.05, n=3)$.

\section{SEM and He-Ion SM}

Detailed insight into the interactions taking place between platelets and cancer cells was enabled by SEM (Figure 6Ai,ii) and He-Ion SM (Figure 6Bi-iv). Figure 6Ai illustrates an
SEM image of a 59M cell-platelet aggregate, whereas a higher magnification image is shown in Figure 6Aii. The He-Ion microscope is particularly suited for imaging biological specimens due to the absence of charging effects traditionally associated with SEM. Furthermore, microscope resolution is less than $0.75 \mathrm{~nm}$. At the onset of platelet aggregation, direct tumour cell-platelet and tumour cell-cell contacts were visible (Figure 6Bi). The platelet network at higher magnification is shown in Figure 6Bii. At the peak of platelet aggregation, platelets became flattened, resulting in the formation of a plaque-like structure (Figure 6Biii,iv).

\section{Effects of inhibitors on P-selectin during TCIPA}

Platelet activation with $59 \mathrm{M}$ cells resulted in a significant $(P<$ $0.01)$ increase in the number of P-selectin copies on platelets (Figure 7A,B), as revealed by the increase in the mean fluorescence intensity. Flow cytometry performed on platelets pre-incubated with $\mathrm{PGI}_{2}, o$-phenanthroline and apyrase showed that these agents significantly inhibited 59Mmediated increase in P-selectin expression $\left(P<0.01\right.$ for $\mathrm{PGI}_{2}$ and $o$-phenanthroline and $P<0.05$ for apyrase) (Figure 7A,B). In contrast, aspirin failed to prevent the increase in platelet surface abundance of the P-selectin protein $(P>0.05)$ (Figure 7A,B). 
A
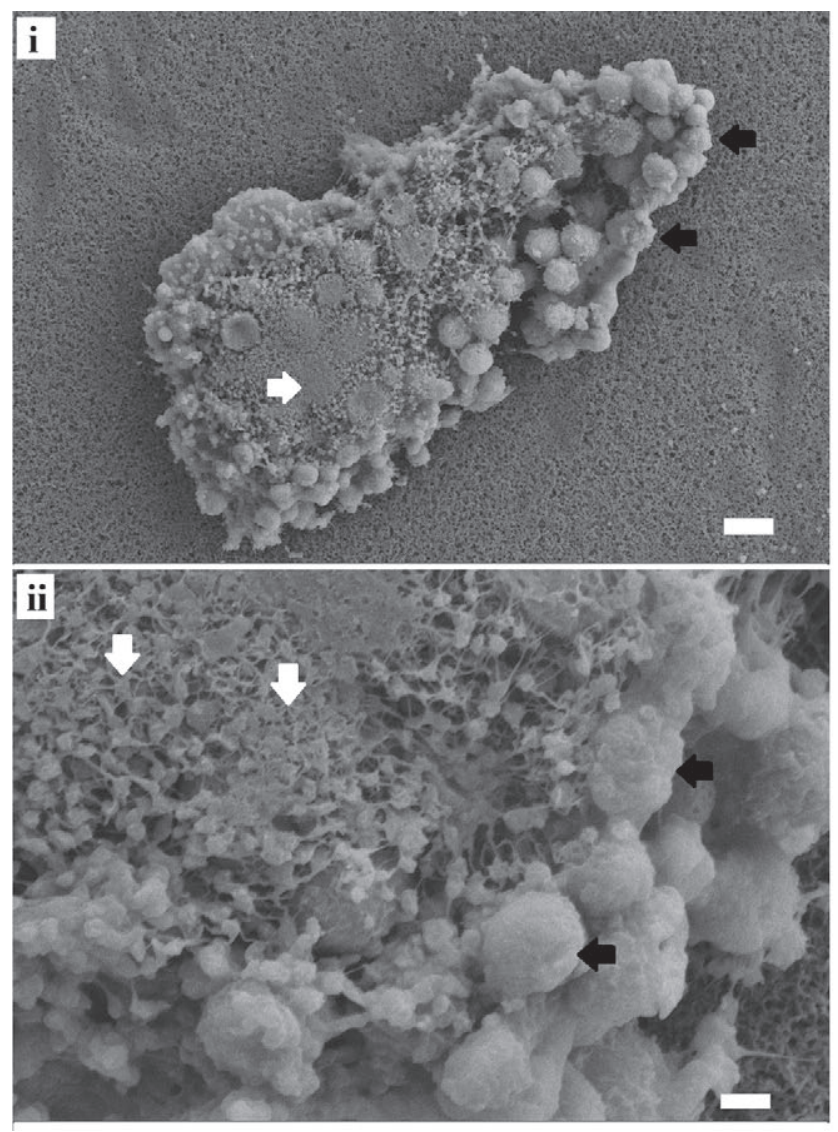

$\mathrm{B}$
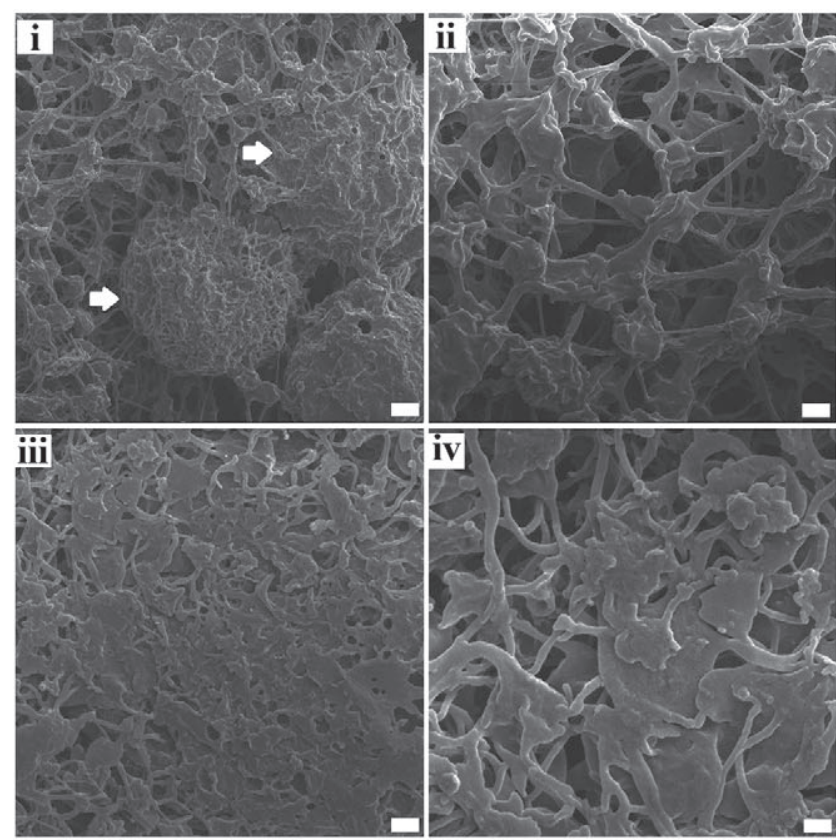

\section{Figure 6}

Scanning electron microscopy (SEM) and He-lon microscopy images of tumour cell-induced platelet aggregation. (A) SEM: (i) Overall and (ii) higher magnification image of 59M tumour cell-platelet aggregate (tumour cells are shown with black arrows, while platelets are shown with white arrows); scale bar in (i) is $40 \mu \mathrm{m}$ and in (ii) $15 \mu \mathrm{m}$. (B) He-lon electron microscopy: (i) At the onset of platelet aggregation, direct tumour-cell-platelet contact was visible; tumour cell-cell contact was also seen (tumour cells are indicated with white arrows); scale bar is $1 \mu \mathrm{m}$; (ii) higher magnification image of the platelet network; scale bar is $500 \mathrm{~nm}$; (iii-iv) at the peak of platelet aggregation, platelet morphology changed to a flattened form, resulting in the development of a plaque. Scale bars are $500 \mathrm{~nm}$ (iii) and $300 \mathrm{~nm}$ (iv).

\section{Discussion and conclusions}

The ability of tumour cells to induce platelet aggregation in vitro correlates with their metastatic capacity in vivo (Honn et al., 1992; Jennings, 2009). Indeed, Jurasz et al. (2003) found that platelets from patients with metastatic prostate cancer were more reactive (as identified by their higher collageninduced aggregation and release of pro-MMP-2) than those from non-metastatic patients. The aim of our study was to investigate TCIPA using a novel USWT.

Some methodological advantages of the USWT include: (i) ultrasound-formed cell clusters are 2-D with extensive cell-cell contacts (as visualized by F-actin immunofluorescence), thus offering an optically accessible cell monolayer; (ii) clusters are levitated in suspension and thus are free of the effects of solid substrata; (iii) mechanically robust and manipulable clusters are formed within $10 \mathrm{~min}$ in the trap; (iv) clusters are 'trapped' in the nodal plane, hence the cell monolayer can be continuously microscopically interrogated in real time; (v) the trap offers the possibility of investigating interactions between different cell types, as shown in the present study between tumour cells and platelets (heterotypic cell clusters) (Bazou et al., 2005a; 2006).

We have studied, in real time, flow-induced TCIPA and have found that perfusion of platelets results in rapid recruitment of platelets to the cancer cell clusters and formation of a tight aggregate. Interestingly, thrombin-stimulated platelets increase the endothelial arrest of cervical cancer cells under shear stress (Liu et al., 2009). Thus, flow is the major factor in platelet-cancer cell interactions.

The key novel finding in our study was that TCIPA resulted in the disruption of the tumour cell aggregate. Platelet activation occurred within an average of $3 \mathrm{~min}$ from platelets-cell aggregate contact, followed by the progressive disruption of the tumour aggregate over the ensuing seconds. This mechanism was established for both cell lines, while the time onset of platelet aggregation and in turn of aggregate disruption was not significantly different for the two cell lines. To the best of our knowledge, no prior report has indicated this property of TCIPA. We suggest that as the platelet morphology changes to a flat one upon aggregation with cancer cells, this results in the generation of a 
A

TCIPA

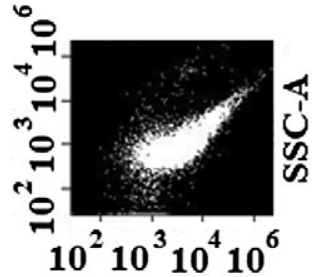

$\mathbf{P G I}_{2}$

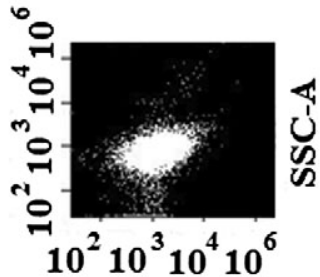

APC-Pselectin Red-A

o-Phenanthroline

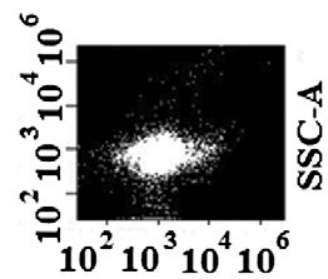

Aspirin

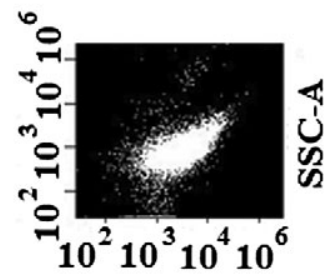

APC-Pselectin Red-A

Apyrase

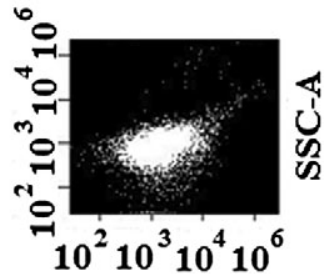

B

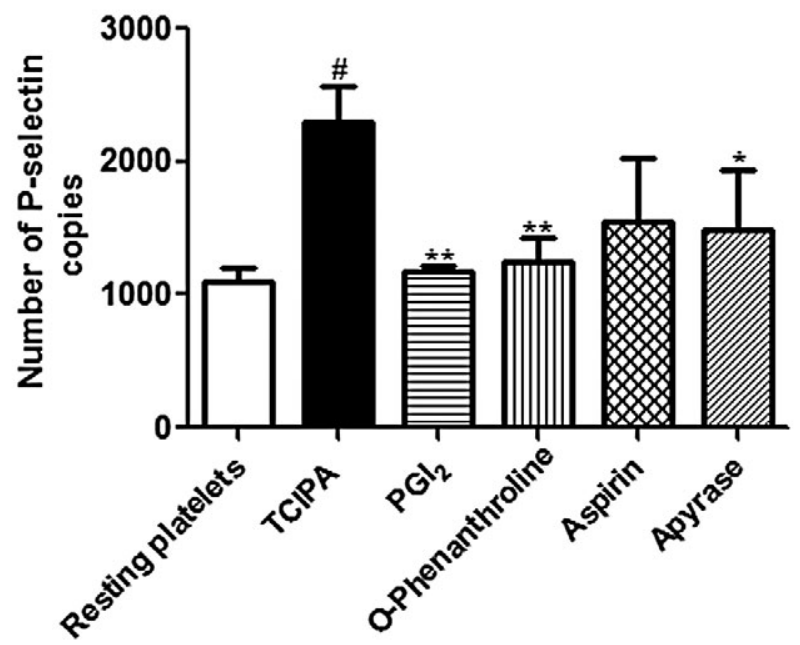

\section{Figure 7}

Presence of P-selectin on platelet membranes during tumour cell-induced platelet aggregation (TCIPA). (A) Flow cytometry recordings showing changes in P-selectin expressed on platelet surfaces during TCIPA and in the presence of different pharmacological inhibitors. (B) Summary data of the expression of P-selectin during TCIPA and in the presence of different pharmacological inhibitors. Resting platelets showed a low expression of $P$-selectin, but on TCIPA, P-selectin expression was significantly increased. Prostacyclin $\left(\mathrm{PGI}_{2}\right)$, o-phenanthroline $(P<0.01)$ or apyrase $(P<0.05)$ significantly reduced the $P$-selectin on the platelet surface, while aspirin exerted no significant effect. $\# P<0.01$, significantly different from resting platelets; ${ }^{*} P<0.05,{ }^{*} P<0.01$, significantly different from TCIPA alone.

mechanical force [platelet contractile force (PCF)] (Carr et al., 2003) that leads to cluster disruption. The discovery of platelet-induced tumour cell disruption represents a novel mechanism that contributes to metastasis. Indeed, rapid disruption and fragmentation of the cluster in the blood stream, in conjunction with distant embolization of vasculature with platelet-cancer aggregates (Malik et al., 1985), may lead to metastasis.

The technique of He-Ion microscopy provided a unique insight into the 'architecture' of cancer cell-platelet aggre- gates. These images showed a topographical view of TCIPA, at sub-nanometer resolution, revealing a complex and intricate network of platelet-platelet and platelet-cancer cell interactions, based on the adhesion of platelet pseudopodia to each other and to the surface of cancer cells. The images showed the areas of flattened platelet aggregates that may be responsible for the generation of the PCF.

We next investigated the role of pathways responsible for platelet aggregation. The relative contribution of each pathway to TCIPA varies between different cancer cells 
(Alonso-Escolano et al., 2004). The ability to arrest TCIPA pharmacologically is a key process in the development of anti-cancer therapies. Tumour cells bind and activate platelets through multiple pathways, thus rendering pharmacological inhibition with the maintenance of adequate haemostasis a significant challenge in human disease (Jurasz et al., 2004; Troxler et al., 2007).

Prostacyclin is the most potent inhibitor of platelet aggregation (Moncada et al., 1976) that inhibits TCIPA (Jurasz et al., 2001b; 2004). We found that although $\mathrm{PGI}_{2}$ inhibited TCIPA in both cell lines, disruption of tumour aggregates was only delayed. The involvement of MMP-2 in TCIPA in vitro has also been acknowledged by several studies (Jurasz et al., 2001b; Medina et al., 2006; Wang et al., 2007). We found that an inhibitor of MMPs, o-phenanthroline, delayed TCIPA induction, while the ADP scavenger apyrase delayed TCIPA only marginally. In contrast, aspirin exerted no significant effect on TCIPA, suggesting that the $\mathrm{TXA}_{2}$ pathway of aggregation is not involved in 59M- and HT1080-induced aggregation, in agreement with previous studies (Camerer et al., 2004; Medina et al., 2006). Only EDTA strongly suppressed TCIPA and cluster rupture. EDTA is a chelating agent that sequesters metallic ions such as $\mathrm{Ca}^{2+}, \mathrm{Mg}^{2+}$ or $\mathrm{Fe}^{3+}$. Clinically, EDTA is used as an antidote in lead poisoning (Bradberry and Vale, 2009); however, EDTA may result in fatal nephrotoxicity. Platelet exposure to EDTA induces changes in the phosphorylation patterns of proteins, followed by extreme distortion of platelet morphology (White et al., 1999). Dissociation of the GPIIb/IIIa complexes has also been reported (Diaz-Ricart et al., 2010). Thus, this remarkable effectiveness of EDTA to arrest flow-induced TCIPA may result from sequestration of different metallic ions. However, this effect may be of limited significance in vivo due to EDTA toxicity. We found that EGTA exerted no significant effect on TCIPA. In contrast to EDTA, EGTA has a higher affinity for $\mathrm{Ca}^{2+}$ than $\mathrm{Mg}^{2+}$, suggesting that chelation of $\mathrm{Ca}^{2+}$ alone is not sufficient to arrest aggregation and cluster disruption. Interestingly, ions including $\mathrm{Fe}^{3+}$ (Kurtoglou et al., 2004), $\mathrm{Mn}^{2+}$ (Sacchetti et al., 1973) and $\mathrm{Zn}^{2+}$ (Heyns et al., 1985) may modulate platelet aggregation. Thus, more than one cation may support flowinduced TCIPA.

We also examined the localization of the activated platelet receptor GPIIb/IIIa ( $\alpha_{\mathrm{IIb}} \beta_{3}$-integrin) and MMP-2 during 59Minduced TCIPA by confocal microscopy. We found that upon TCIPA, the activated (PAC-1-labelled) GPIIb/IIIa was colocalized with MMP-2 to the platelet surface. Furthermore, zymography showed that pro-MMP-2/MMP-2 was released during TCIPA. Martinez et al. (2001) has previously shown that the release of platelet MMP-2 is associated with the activation of the GPIIb/IIIa receptor, while Choi et al. (2007) demonstrated that MMP-2 co-immunoprecipitates with $\alpha_{\mathrm{II}} \beta_{3}$-integrin. This interaction is required in order for platelets to be fully activated and the catalytic activity of the enzyme is essential to exert the molecular function of MMP-2 in the bimolecular complex (Choi et al., 2007). Our co-localization data in conjunction with the release of MMP-2 support these observations. We also detected increased MMP-9 release during TCIPA and this release may attenuate the pro-aggregatory activity of MMP-2 (Fernandez-Patron et al., 1999).

Another platelet receptor known to engage in adhesion and aggregation of platelets is P-selectin (Läubli and Borsig,
2010). P-selectin is present in platelet $\alpha$-granules and upon activation is rapidly expressed on the cytoplasmic membrane. P-selectin contributes to the thrombi formation and aids the colonization of cancer cells in the lungs (Kim et al., 1998). In addition, platelets bind to cancer cells through carcinoma cell surface mucins in a P-selectin-dependent manner (Borsig et al., 2001). Therefore, we studied the changes in the abundance of platelet P-selectin, induced by 59M cells. 59M cells increased P-selectin as measured by flow cytometry. Furthermore, the inhibition of the MMP-2 or the ADP-mediated pathways of platelet aggregation significantly reduced P-selectin, while the inhibition of the $\mathrm{TXA}_{2}$-mediated pathway exerted no significant effect. In contrast, $\mathrm{PGI}_{2}$ decreased P-selectin expression. Although flow cytometry data are in good agreement with the pharmacology, it is clear that reduction in P-selectin was not sufficient to arrest TCIPA and inhibit tumour aggregate disruption.

In conclusion, we have reported a novel mechanism involved in TCIPA; platelet-induced disruption of cancer cell clusters. This mechanism was consistently observed with both cell lines used here, in terms of pattern and time course. Pharmacological modulation of TCIPA, with inhibitors of platelet activation such as $\mathrm{PGI}_{2}$, apyrase and $o$-phenanthroline, but not aspirin or EGTA, delayed the rupture of cancer cell clusters. None of the tested inhibitors completely arrested TCIPA and tumour aggregate disruption, with the exception of EDTA. As our model successfully mimics TCIPA, it may be used to develop new pharmacological strategies to arrest TCIPA and prevent disruption of cancer cell clusters in vivo.

\section{Acknowledgements}

The authors would like to acknowledge Dr C. Reid (CMA), Dr $\mathrm{H}$. Zhang and his team (AML) for their assistance with the scanning electron microscopy. We are grateful for the financial support to DB as an EU Marie Curie Fellowship (MTKDCT-2006-042519 - Nanofab), and to MWR/MJSM from the Science Foundation, Ireland, and to CM, Stokes Lectureship, Science Foundation, Ireland.

\section{Conflict of interest}

None

\section{References}

Alonso-Escolano D, Strongin AY, Chung AW, Deryugina EI, Radomski MW (2004). Membrane type-1 matrix metalloproteinase stimulates tumour cell-induced platelet aggregation: role of receptor glycoproteins. Br J Pharmacol 141: 241-252.

Angiolillo DJ, Ueno M, Goto S (2010). Basic principles of platelet biology and clinical implications. Circ J 74: 597-607.

Bazou D, Kuznetsova LA, Coakley WT (2005a). Physical environment of 2-D animal cell aggregates formed in a short pathlength ultrasound standing wave trap. Ultrasound Med Biol 31: 423-430. 
Bazou D, Foster GA, Ralphs JR, Coakley WT (2005b). Molecular adhesion development in a neural cell monolayer forming in an ultrasound trap. Mol Membr Biol 22: 229-230.

Bazou D, Dowthwaite GP, Khan IM, Archer CW, Ralphs JR, Coakley WT (2006). Gap junctional intercellular communication and cytoskeletal organization in chondrocytes in suspension in an ultrasound trap. Mol Membr Biol 23: 195-205.

Borsig L (2008). The role of platelet activation in tumour metastasis. Expert Rev Anticancer Ther 8: 1247-1255.

Borsig L, Wong R, Feramisco J, Nadeau DR, Varki NM, Varki A (2001). Heparin and cancer revisited: mechanistic connections involving platelets, P-selectin, carcinoma mucins, and tumour metastasis. Proc Natl Acad Sci USA 98: 3352-3357.

Bradberry S, Vale A (2009). A comparison of sodium calcium edetate (edetate calcium disodium) and succimer (DMSA) in the treatment of inorganic lead poisoning. Clin Toxicol (Phila) 47: 841-848.

Camerer E, Qazi AA, Duong DN, Cornelissen I, Advincula R, Coughlin SR (2004). Platelets, protease-activated receptors, and fibrinogen in hematogenous metastasis. Blood 104: 397-401.

Carr ME Jr, Angchaisuksiri P, Carr SL, Martin EJ (2003). Effect of non-heparin thrombin antagonists on thrombin generation, platelet function, and clot structure in whole blood. Cell Biochem Biophys 39: 89-89.

Choi W-S, Jeon O-H, Kim H-H, Kim DH (2007). MMP-2 regulates human platelet activation by interacting with integrin $\alpha_{\mathrm{IIb}} \beta_{3}$. J Thromb Haemost 6: 517-523.

Diaz-Ricart M, Brunso L, Pino M, Navalon F, Jou JM, Heras M et al. (2010). Preanalytical treatment of EDTA-anticoagulated blood to ensure stabilisation of the mean platelet volume and component measured with the ADVIA counters. Thromb Res 126: e30-e35.

Erpenbeck L, Schön MP (2010). Deadly allies: the fatal interplay between platelets and metastasizing cancer cells. Blood 115: 3427-3486.

Fernandez-Patron C, Martinez-Cuesta MA, Salas E, Sawicki G, Wosniak M Radomski MW et al. (1999). Differential regulation of platelet aggregation by matrix metalloproteinases- 9 and -2 . Thromb Haemost 82: 1730-1735.

Gfeller KY, Nugaeva N, Hegner M (2005). Rapid biosensor for detection of antibiotic-selective growth of Escherichia coli. Appl Environ Microbiol 71: 2626-2231.

Heyns AP, Eldor A, Yarom R, Marx G (1985). Zinc-induced platelet aggregation is mediated by the fibrinogen receptor and is not accompanied by the release or by thromboxane synthesis. Blood 66: 213-219.

Honn KV, Tang DG, Crissman JD (1992). Platelets and cancer metastasis: a causal relationship? Cancer Metastasis Rev 11: 325-331.

Ho-Tin-Noé B, George T, Cifuni SM, Duerschmied D, Wagner DD (2008). Platelet granule secretion continuously prevents intratumour hemorrhage. Cancer Res 68: 6851-6858.

Ho-Tin-Noé B, Goerge T, Wagner DD (2009). Platelets: guardians of tumour vasculature. Cancer Res 69: 5623-5626.

Jennings LK (2009). Mechanisms of platelet activation: need for new strategies to protect against platelet-mediated atherothrombosis. Thromb Haemost 102: 248-257.

Jurasz P, Stewart MW, Radomski A, Khadour F, Duszyk M, Radomski MW (2001a). Role of von Willebrand factor in tumour cell-induced platelet aggregation: differential regulation by NO and prostacyclin. Br J Pharmacol 134: 1104-1112.
Jurasz P, Sawicki G, Duszyk M, Sawicka J, Miranda C, Mayers I et al. (2001b). Matrix metalloproteinase 2 in tumour cell-induced platelet aggregation: regulation by nitric oxide. Cancer Res 61: 376-382.

Jurasz P, North S, Venner P, Radomski MW (2003). Matrix metalloproteinase- 2 contributes to increased platelet reactivity in patients with metastatic prostate cancer: a preliminary study. Thromb Res 112: 59-64.

Jurasz P, Alonso-Escolano D, Radomski MW (2004). Platelet-cancer interactions: mechanisms and pharmacology of tumour cellinduced platelet aggregation. Br J Pharmacol 143: 819-826.

Jurk K, Kehrel BE (2005). Platelets: physiology and biochemistry. Semin Thromb Hemost 31: 381-392.

Khorana AA, Fine RL (2004). Pancreatic cancer and thromboembolic disease. Lancet Oncol 5: 655-663.

Kim YJ, Borsig L, Varki NM, Varki A (1998). P-selectin deficiency attenuates tumour growth and metastasis. Proc Natl Acad Sci USA 95: 9325-9330.

Kurtoglou E, Ugur A, Baltaci AK, Helifeoglou I (2004). Effects of trace element levels on platelet aggregation. Biol Trace Elem Res 99: 93-98.

Läubli H, Borsig L (2010). Selectins promote tumour metastasis. Semin Cancer Biol 20: 167-177.

Lim MC, Lee HS, Kang S, Seo S-S, Lee BY, Park S-Y (2010). Minimizing tumor burden by extensive cytoreductive surgery decreases postoperative venous thromboembolism in ovarian clear cell carcinoma. Arch Gynecol Obstet 281: 329-334.

Linenberger ML, Wittkovsky AK (2005). Thromboembolic complications of malignancy. Part 1: risks. Oncology 19: 853-861.

Liu Y, Zhao F, Gu W, Yang H, Meng Q, Zhang Y et al. (2009). The roles of platelet GPIIb/IIIa and alphavbeta3 integrins during HeLa cells adhesion, migration, and invasion to monolayer endothelium under static and dynamic shear flow. J Biomed Biotechnol 2009: 829243.

Malik AB, Selig WM, Burhop KE (1985). Cellular and humoral mediators of pulmonary edema. Lung 163: 193-199.

Martinez A, Salas E, Radomski A, Radomski MW (2001). Matrix metalloproteinase-2 in platelet adhesion to fibrinogen: interactions with nitric oxide. Med Sci Monit 7: 646-651.

Medina C, Jurasz P, Santos-Matrinez MJ, Jeong SS, Mitsky T, Chen $\mathrm{R}$ et al. (2006). Platelet aggregation-induced by Caco- 2 cells: regulation by matrix metalloproteinase- 2 and adenosine diphosphate. J Pharmacol Exp Ther 317: 739-745.

Moncada S, Grygliewski R, Bunting S, Vane JR (1976). An enzyme isolated from arteries transforms prostaglandin endoperoxides to an unstable substance that inhibits platelet aggregation. Nature 263: 663-665.

Nierodzik ML, Karpatkin S (2006). Thrombin induces tumour growth, metastasis, and angiogenesis: evidence for a thrombinregulated dormant tumour phenotype. Cancer Cell 10: 355-362.

Palumbo JS, Talmage KE, Massari JV, La Jeunesse CM, Flick MJ, Kombrinck KW et al. (2005). Platelets and fibrin(ogen) increase metastatic potential by impeding natural killer cell-mediated elimination of tumour cells. Blood 105: 178-185.

Philippe C, Philippe B, Fouqueray B, Perez J, Lebret M, Baud L (1993). Protection from tumour necrosis-factor-mediated cytolysis by platelets. Am J Pathol 143: 1713-1723. 
Radomski M, Moncada S (1983). An improved method for washing of human platelets with prostacyclin. Thromb Res 30: 383-389.

Radomski A, Jurasz P, Alsonso-Escolano D, Drews M, Morandi M, Malinski T et al. (2005). Nanoparticle-induced platelet aggregation and cascular thrombosis. Br J Pharmacol 146: 882-893.

Sacchetti G, Gibelli A, Bellani D, Montanari C (1973). Effect of manganese ions on human platelet aggregation in vitro. Experientia 30: 374-375.

Santos-Martinez MJ, Medina C, Jurasz P, Radomski MW (2008). Role of metalloproteinases in platelet function. Thromb Res 121: 535-542.

Sawicki G, Salas E, Murat J, Miszta-Lane H, Radomski MW (1997). Release of gelatinase A during platelet activation mediates aggregation. Nature 386: 616-629.

Sørensen HT, Mellemkjaer L, Steffensen FH, Olsen JH, Nielsen GL (1998). The risk of diagnosis of cancer after primary deep venous thrombosis or pulmonary embolism. N Engl J Med 338: 1169-1173.

Trousseau A (1865). Phlegmatia Alba Dolens, Vol. 3. JB Baillere et Fils: Paris, pp. 654-662.

Troxler K, Dickinson K, Homer-Vanniasinkam S (2007). Platelet function and antiplatelet therapy. Br J Surg 94: 674-682.

Varga-Szabo D, Pleines I, Nieswandt B (2008). Cell adhesion mechanisms in platelets. Arterioscler Thromb Vasc Biol 28: 403-412.

Von Tempelhoff G-F, Niemann F, Schneider DM (1998). Blood rheology during chemotherapy in patients with ovarian cancer. Thromb Res 90: 73-82.

Wahrenbrock M, Borsig L, Le D, Varki N, Varki A (2003). Selectin-Mucin interactions as a probable molecular explanation for the association of Trousseau syndrome with mucinous adenocarcinomas. J Clin Invest 112: 853-862.

Wang JS, Chang CY, Chow SE, Chen YW, Yang CM (2007). Exercise modulates platelet-nasopharyngeal carcinoma cell aggregation and subsequent tissue factor and matrix metalloproteinase activities. J Appl Physiol 103: 763-770.
White JG, Krumwiede MD, Escolar G (1999). EDTA induced changes in platelet structure and function: influence on particle uptake. Platelets 10: 327-337.

Winter PC (2006). The pathogenesis of venous thromboembolism in cancer: emerging links with tumour biology. Hematol Oncol 24: 126-133.

\section{Supporting information}

Additional Supporting Information may be found in the online version of this article:

Figure S1 Pharmacological inhibition of TCIPA for the (A) $59 \mathrm{M}$ and (B) HT1080 cell lines under static conditions. PGI2, $o$-phenanthroline and apyrase significantly down-regulated TCIPA in both cell lines $(P<0.05 ; P<0.01$ for the $59 \mathrm{M}$ cells in the presence of $\mathrm{PGI}_{2}$ ). Pre-incubation of platelets with aspirin exerted no significant effect.

Figure S2 Pre-incubation of platelets with EGTA exerted no significant effect on 59M-induced platelet aggregation under static conditions $(P>0.05)$.

Figure S3 The release of gelatinases during 59M-induced TCIPA. (A) Representative zymogram showing the gelatinolytic activities of MMP-2 and MMP-9; (B) and (C) Densitometric analysis of the effects of gelatinases $(P<0.05$ TCIPA vs. $59 \mathrm{M}$ release, $n=3$ ). The conditioned medium of HT1080 cells served as the gelatinase standard.

Video S1 Real-time video of TCIPA in the USWT.

Please note: Wiley-Blackwell are not responsible for the content or functionality of any supporting materials supplied by the authors. Any queries (other than missing material) should be directed to the corresponding author for the article. 